\title{
A new hybrid in the genus Antbyllis (Loteae-Leguminosae) from the eastern Iberian Peninsula
}

\author{
P. Pablo Ferrer-Gallego ${ }^{1,2 *}$, Roberto Roselló $\&$ Miguel Guara ${ }^{4}$ \\ ${ }^{1}$ Servicio de Vida Silvestre, Centro para la Investigación y Experimentación Forestal (CIEF), Avda. Comarques del País Valencià, n. ${ }^{\circ}$ 114, E-46930, Quart \\ de Poblet, Spain; flora.cief@gva.es \\ ${ }^{2}$ VAERSA, Avda. Cortes Valencianas, n. ${ }^{\circ}$ 20, E-46015, Valencia, Spain \\ ${ }^{3}$ IES Jaume I, Plaça Sanchis Guarner s.n., E-12530, Borriana, Spain; rrosello514k@cv.gva.es \\ ${ }^{4}$ Departament de Botànica, Universitat de València, Facultat de Ciències Biològiques, Avda. Dr. Moliner, n. ${ }^{\circ}$ 50, E- 46100, Burjassot, Spain; \\ Miguel.Guara@uv.es
}

Recibido: 5-VII-2012; Aceptado: 5-VII-2013; Publicado on line: 11-XI-2016

\begin{abstract}
Ferrer-Gallego, P.P., Roselló, R. \& Guara, M. 2016. A new hybrid in the genus Anthyllis (Loteae-Leguminosae) from the eastern Iberian Peninsula. Anales Jard. Bot. Madrid 73(2): e040.

We describe a new nothotaxon for the genus Anthyllis (LoteaeLeguminosae), A. × currasii P.P. Ferrer, Roselló \& Guara, as result of natural interbreeding between $A$. cytisoides (Lag.) Pau and A. lagascana Benedí. It has been located at Monte de La Cañada, in Paterna (Valencia, Spain). This new hybrid is compared morphologically with its parents and the rest of nothotaxa described hitherto for the genus in the Iberian Peninsula, analysing the main diagnostic characters. The existence of the nothotaxa A. × fortuita Guara \& P.P. Ferrer and A. x currasii implies the creation of the new nothosubgenus Ternijovis P.P. Ferrer, Rosello \& Guara. A map of the known and documented distribution is presented. Iconography of the three nothotaxa is provided, and an identification as well.
\end{abstract}

Keywords: Anthyllis, Leguminosae, nomenclature, nothotaxa, taxonomy.

\section{Resumen}

Ferrer-Gallego, P.P., Roselló, R. \& Guara, M. 2016. Un nuevo híbrido en el género Anthyllis (Loteae-Leguminosae) del este de la Península Ibérica. Anales Jard. Bot. Madrid 73(2): e040.

Se describe Anthyllis × currasii P.P. Ferrer, Roselló \& Guara, un nuevo híbrido para el género Anthyllis (Loteae-Leguminosae), producto del cruce natural entre $A$. cytisoides (Lag.) Pau y A. lagascana Benedí, y hallado en el Monte de La Cañada de Paterna (Valencia, España). El nuevo híbrido se compara morfológicamente con sus dos parentales y con los restantes híbridos hasta ahora descritos para el género Anthyllis que viven en la Península Ibérica, analizando los principales caracteres diagnósticos. Los los nothotáxones $A$. × fortuita Guara \& P.P. Ferrer y A. × currasii implican la creación de un nuevo nothosubgénero: Ternijovis P.P. Ferrer, Roselló \& Guara. Se aporta un mapa de distribución, ilustraciones de los tres nothotáxones y una clave de identificación para este grupo de plantas.

Palabras clave: Anthyllis, Leguminosae, nomenclatura, nothotaxon, taxonomía.

Copyright: ( 2016 CSIC. This is an open-access article distributed under the terms of the Creative Commons Attribution (CC-by) Spain 3.0 License.

\section{INTRODUCTION}

The genus Anthyllis L. (Loteae-Leguminosae) includes 23 species and is distributed throughout Europe (excluding the Northeastern and Southeastern regions), Madeira, Northern and Eastern Africa, and Western Asia, although most of the genera are distributed along the Midwestern Mediterranean basin (Sokoloff, 2003a; Degtjareva \& al., 2006). Currently, the monophyletic nature of the genus has been established (including Hymenocarpos Savi, but excluding Dorycnopsis Boiss. and the monotypic Tripodion Medik.) after a deep revision of the phylogeny with new molecular information (Tikhomirov \& Sokoloff, 1996b; Sokoloff, 2003a; Nanni \& al., 2004; Degtjareva \& al., 2006; Degtjareva \& al., 2012).

These phylogenetic studies have provided a clear delimitation of Antbyllis from other genera within the tribe Loteae. Occasionally, however, the narrow morphological similarity and close phylogenetic proximity of some species (see Tikhomirov \& Sokoloff, 1996a, 1996b; Sokoloff, 2006) have caused the inclusion of certain taxa within Antbyllis (e.g., Dorycnopsis Boiss. within Antbyllis, cf. López González, 2004), although this proximity has been explained by evolutionary parallelism in most cases (Degtjareva \& al., 2006). It is now accepted that Anthyllis is divided into four subgenera (Tikhomirov \& Sokoloff, 1996b; Sokoloff, 2003a), which include: $A$. subgen. Anthyllis, A. subgen. Barba-Jovis V.N. Tikhom \& D.D. Sokoloff, $A$. subgen. Cornicina (DC.) Akulov ex V.N. \& D.D. Sokoloff y $A$. subgen. Terniflora V.N. Tikhom \& D.D. Sokoloff. However, Benedí (1998) used a slightly different taxonomic treatment, and adopted a subdivision into sections according to Tikhomirov \& Sokoloff (1996b), which is described as follows.

According to Benedí (2000), the Iberian Antbyllis includes 12 taxa at the rank of species or subspecies (11 of which belong to the complex A. vulneraria L.). Among them, 8 (excluding A. sect. Antbyllis) have a wide distribution in the Southeastern Iberian Peninsula, mainly in the provinces of Valencia, Alicante, Albacete, Almeria, and Murcia. Anthyllis cytisoides L., Sp. Pl.: 720 (1753) is a very abundant plant, important as structural element ofvegetation within the landscape of these areas. It is widely spread across the Spanish territory and it is prone to natural hybridization with $A$. terniflora (Lag.) 
Pau, Bull. Acad. Int. Géogr. Bot. 16(2): 75 (1906) (cf. Rigual, 1984; Sagredo, 1987; De la Torre, 1988; Crespo, 1989; Crespo \& Manso, 1990; Vicedo \& De la Torre, 1997; Sánchez-Gómez \& al., 2003; Serra, 2007; Mateo \& Crespo, 2014). By contrast, A. lagascana Benedí, Anales Jard. Bot. Madrid 53(2): 283 (1995) is an bero-Maghrebian species with a restricted distribution in the Southeastern Iberian Peninsula and Northwestern Africa, and hybridization with A. terniflora (Guara \& Ferrer, 2006).

Both $A$. cytisoides and $A$. lagascana coexist in a small area within the municipality of Paterna (Valencia, Spain), where $A$. cytisoides has a relatively low number of specimens, in comparison with $A$. lagascana,much more common and widely distributed in this area. Despite the low abundance of $A$. cytisoides, we have detected several plants with clearly intermediate characters between these two species. In addition, $A$. terniflora and their hybrids also live in the same area, $A$. $\times$ media Pau, Mem. Mus. Ci. Nat. Barcelona, Sèr. Bot. 1(3): 16 (1925) (A. cytisoides $\times$ A. terniflora) and A. $\times$ fortuita Guara \& P.P. Ferrer, Act. Bot. Malac. 31: 171 (2006) (A. lagascana $\times$ A. terniflora).

The aim of this paper is thus to describe a new nothotaxon between $A$. cytisoides and A. lagascana, based on morphology as primary criterion of hybridization.

\section{MATERIALS AND METHODS}

The studied herbarium sheets are kept at $\mathrm{ABH}, \mathrm{BC}$, MA, MUB, and VAL herbaria (Thiers, 2016). Additional materials from authors' personal collections of $A$. cytisoides, A. lagascana, A. terniflora, $A$. ×media, and $A . \times$ fortuita were also used (Appendix 1).

The criteria used to identify the species of Antbyllis include observations of qualitative and quantitative characters (cf. Cullen, 1968; Benedí, 1995, 1998, 2000; Tikhomirov \& Sokoloff, 1996b; Sokoloff, 1997, 2003b, 2006). A total of 35 characters have been analyzed; 13 of them were scored as qualitative characters (simple presence $v$ s. absence) or multistate characters related to the basal leaves (disposition, number of leaflets, and termination), the terminal leaflet shape, the indumentum of leaves, the petiolar covering and hairiness at leave bases, the calyx (general morphology, teeth form, and type and density of indumentum), the colour of petals, the shape of the style, and the morphology and ornamentation of the legumes and seeds (Table 1 ).

The rest of characters (22) were quantitative (21 continous and 1 meristic -count-) related to the length and width of terminal leaflets and lateral ones, the calyx and its teeth, the banner and wings, the legumes and seeds; the length of inflorescences, flowers, claw of the banner, keels and stipules, and the number of flowers in the inflorescence. We have considered only three to five measurements per sheet.

\section{RESULTS}

Anthyllis $\times$ currasii P.P. Ferrer, Roselló \& Guara, nothosp. nov. (Figs. 1, 2, and 3).

$$
\text { Anthyllis cytisoides L. } \times \text { A. lagascana Benedí. }
$$

A Anthyllis cytisoides, foliis trifoliatis, inferioribus dense imbricatis et distichis, cum exiccato subamplexicaulo persistente petiolo, subpulvinulatis, bracteis palmatisectis, calicibus minoribus et campanulatis, cum indumento sericeo erectopatente, corolis rosaceis, vexili lamina iuxta alas et carinam minore magnitudine differt. A A. lagascana, foliis stipulatis, inflorescentia in terminalibus et laxis spicis cum paucifloreis fasciculis 1-4(5) floribus, non glomerularibus nec pedunculatis; bracteis simplicibus; calicibus minoribus; corolis luteis differt. Botanico Dr. Ing. Rafael Currás Cayón amigo et magister ex animo dicata nothospecies.

Type: Spain. Valencia: Paterna (l'Horta), El Plantío-La Canyada, antiguo campo de cultivo de algarrobos abandonado con matorral y pinar de Pinus halepensis in solo calcareis, 30SYJ1579, 123 m, P.P. Ferrer E I. Ferrando s.n., 23 May 2008 [holotype: MA 776378 (Fig. 2); isotypes: ABH 52762, BC 990270, VAL].

Shrub up to $50-80 \mathrm{~cm}$, woody, unarmed, ash-gray; young branches herbaceous, erect, grayish-white or gray, with dense indumentum of applied-sericeous hairs with other crispate both the bottom and top of the stem. Branchlets densely leafy, covered at the base by the scarious petioles of dry leaves arranged distichously and densely imbricated, somewhat amplexicaul and persistent; branches of previous years intricate-flexuous, with gray and fissured bark; leaves usually trifoliate, at the apex mucronate and somewhat canaliculate, with indumentum appressed sericeous to silky-pilose, glaucous, subpulvinate; with terminal leaflet $(5) 13-18(19) \times 3-7 \mathrm{~mm}$, occasionally single, much larger than the lateral ones, lanceolate to ovate or elliptical, sometimes somewhat orbiculate, with peduncle 0.5-2 mm; lateral leaflets $3-6(7) \times 1-3 \mathrm{~mm}$, lanceolate to elliptical; petiole amplexicaul at base, persistent; stipules up to $0.5 \mathrm{~mm}$, very sharp, setaceous, and dark brown. Inflorescences in terminal and lax spikes of 1-4(5) flowered clusters, axillary, almost sessile or with peduncle up to c. 2 $\mathrm{mm}$, some with malformed or aborted flowers, the last ones of the inflorescence next each other; bracts palmate, or simply lanceolate, with the same size as flowers, or slightly shorter. Flowers 9-11 mm. Calyx 6-6.5 × c. $2 \mathrm{~mm}$, campanulate, very pilose, with erect-patent hairs up to c. $1 \mathrm{~mm}$, with oblique mouth tube; teeth c. $2 \mathrm{~mm}$, triangular, narrowly acuminated. Corolla pale yellow to cream with pink hues, darkening on drying; banner blade 5.5-6 $\times 3.3 .5 \mathrm{~mm}$ from oblong-ovate to ovate-oblong, the base slightly cordate or abruptly attenuated with a claw $4 \mathrm{~mm}$; wings blade c. $4 \times 1-1.2 \mathrm{~mm}$, lanceolate, and claw c. $4.5 \mathrm{~mm}$, exceeding c. $1 \mathrm{~mm}$ the keel; keel blade c. $3 \mathrm{~mm}$, bent somewhat straight; vexillary stamen free only near the base. Ovary with 7-11 seed rudiments; style c. $4 \mathrm{~mm}$, slightly arched, flattened at the base. Fruit $4 \times 2 \mathrm{~mm}$, ellipsoid, slightly arched, somewhat stipitate, even finely reticulated. Seeds c. $2.1 \times 1.2 \mathrm{~mm}$, slightly reniform, smooth, brownish grey (Fig. 1; Table 1).

Plant morphological characters were intermediate between $A$. cytisoides and $A$. lagascana. This newly described hybrid differs from $A$. lagascana by the presence of foliar stipules (Fig. 8), somewhat amplexicaul and not invaginating leaf sheaths; axillary almost sessile inflorescences with 1-4(5) flowers, clustered in terminal and lax spikes, never in pedunculated glomeruli; presence of some simple bracts, sometimes bifoliate or trifoliate; minor calyx with long and 


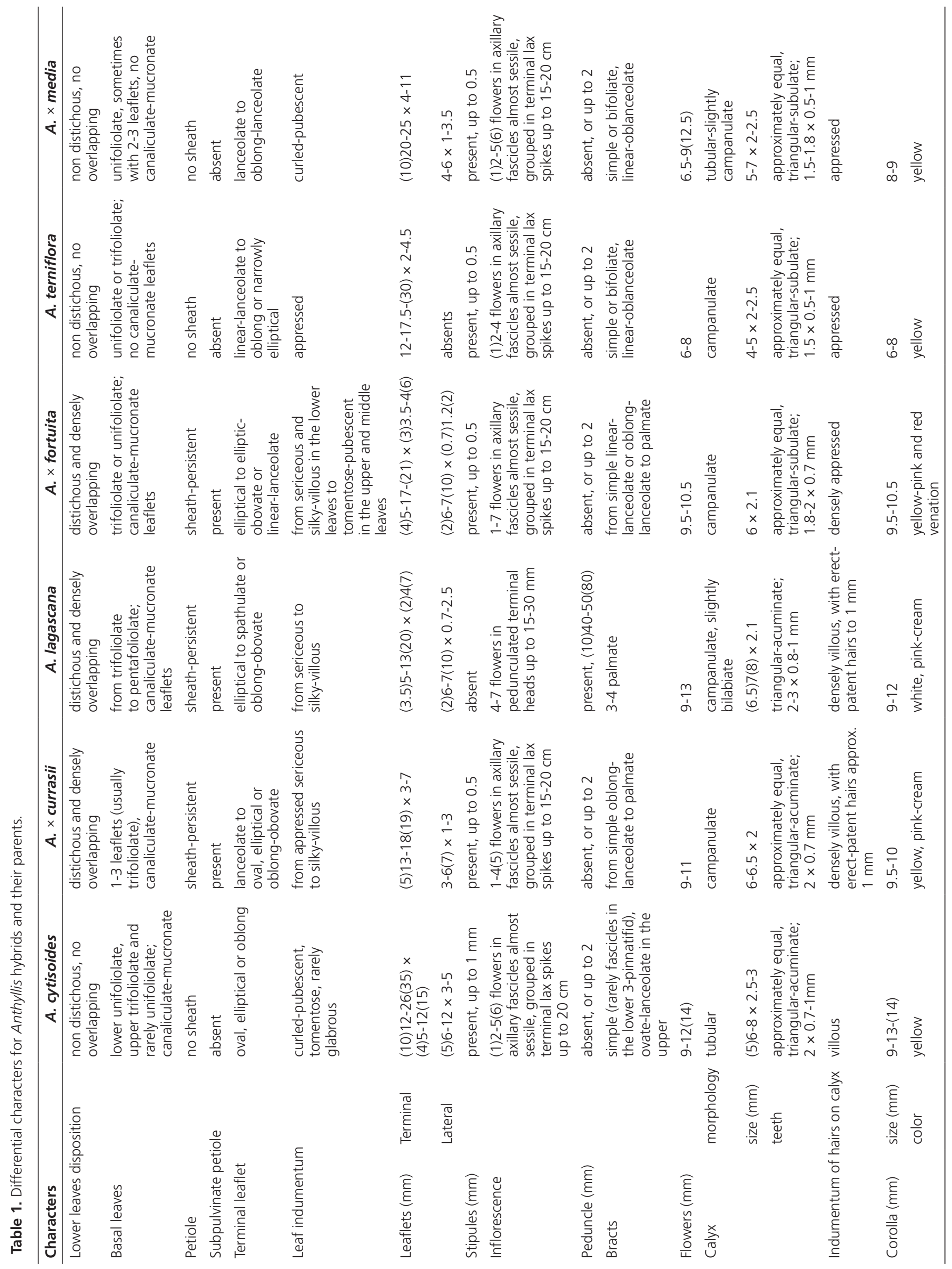




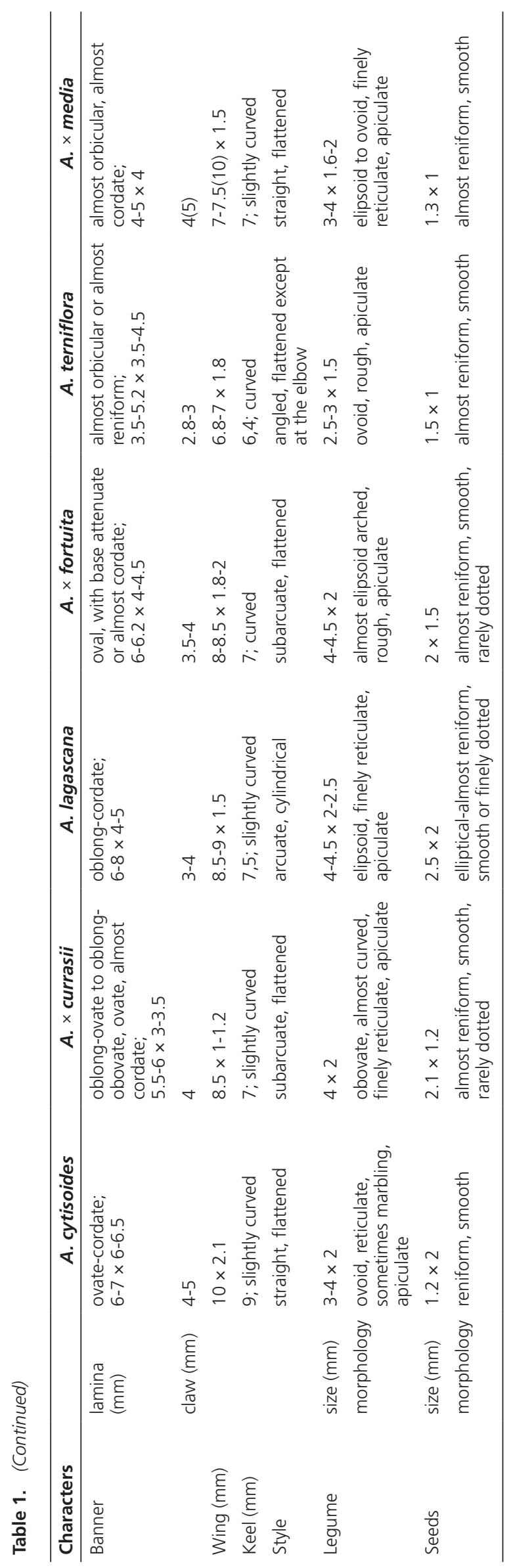




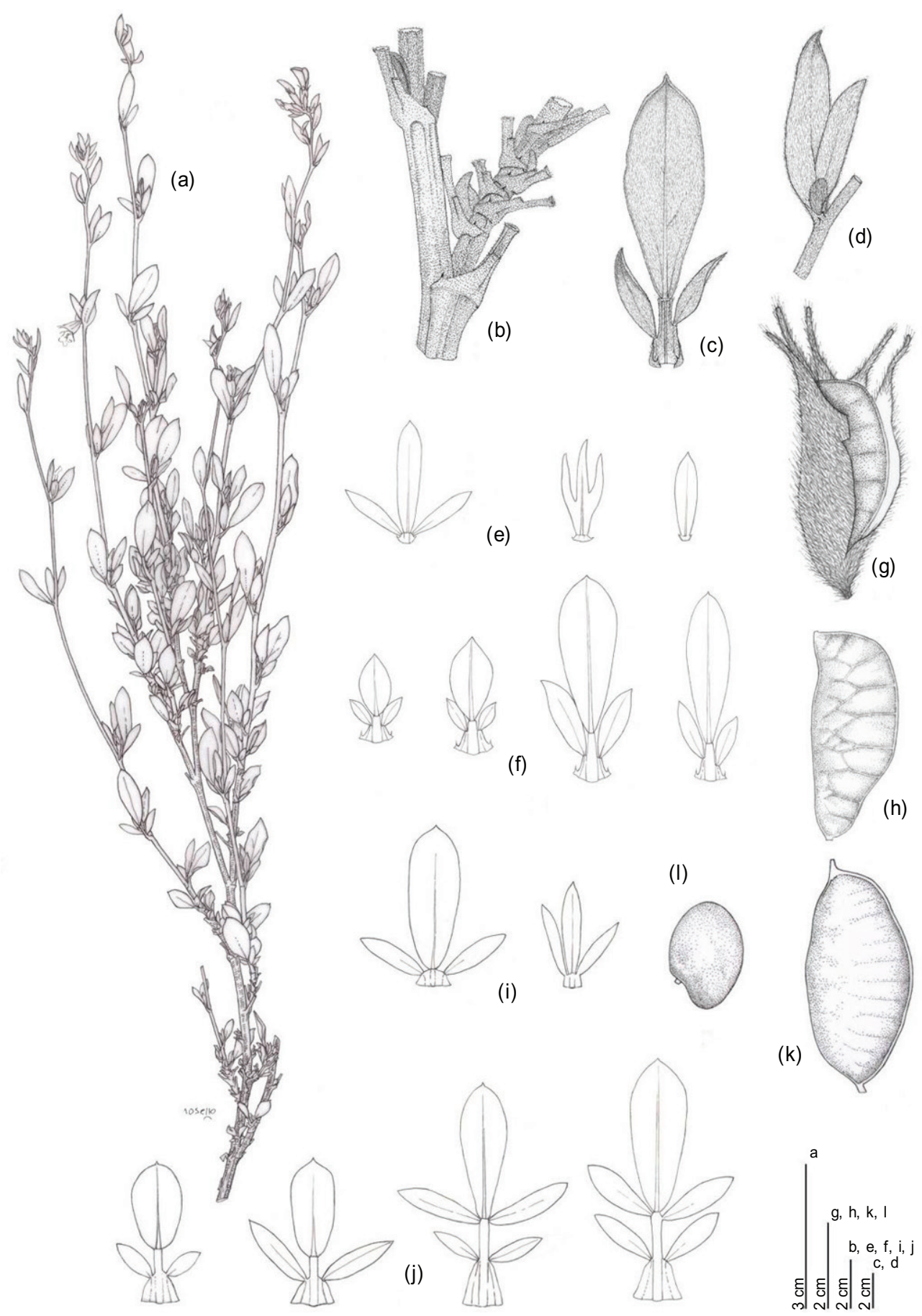

Fig. 1. Anthyllis $\times$ currasii: $\mathbf{a}$, habit; $\mathbf{b}$, branch and petioles of basal leaves; $\mathbf{c}$, leaf; $\mathbf{d}$, unifoliolate leaf; $\mathbf{e}$, bracts; $\mathbf{f}$, leaves; $\mathbf{g}$, calyx and fruit; $\mathbf{h}$, fruit. A. lagascana: i, bracts; j, leaves; k, fruit; I, seed [a-h, P.P. Ferrer \& I. Ferrando s.n. (MA 776378); i-I, P.P. Ferrer \& I. Ferrando s.n. (MA 776380)]

narrowly acuminated teeth (never triangular flattened); and yellow and smaller corollas (Figs. 1 and 7 ). Anthyllis $\times$ currasii also differs from $A$. cytisoides by the presence of subpulvinate unifoliolate leaves, the lower ones densely imbricated and distichous; persistent and somewhat amplexicaul dried petioles; presence of palmately divided bracts; campanulate calyx (not tubular), with a cream or greenish hue (not canary yellow); corolla, banner, wings and keel clearly smaller; and ellipsoidal fruit (not ovoid) (Figs. 6 and 7; Table 1). It is noteworthy the presence of subpulvinate petiole and foliar stipules, entire and palmately divided bracts, and mediumsized floral pieces (Figs. 7 and 8; Table 1).

Anthyllis $\times$ currasii can be easily differentiated from A. $\times$ fortuita by the smaller number of flowers of the spike, the markedly more ash-grey colour, erect-patent calyx indumentum, larger calyxes, and oblong banner blade (Figs. 5 and 7). The remaining most significant morphological differences with the rest of the group are summarized in Table 1. The authors would like to note some variability among the specimens of $A$. $\times$ fortuita. Such variation mainly affects the 


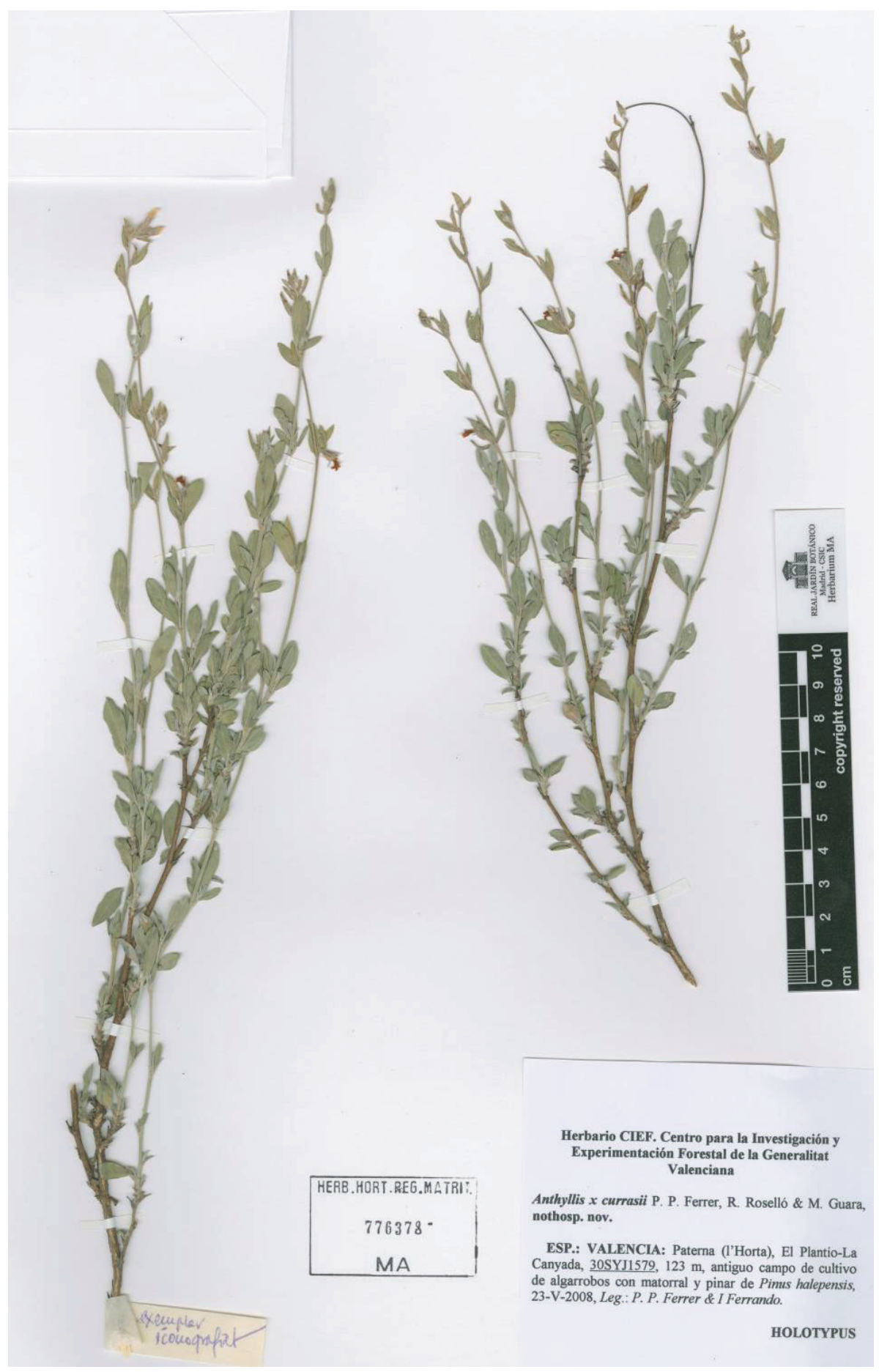

Fig. 2. Anthyllis $\times$ currasii: holotype [P.P. Ferrer \& I. Ferrando s.n. (MA 776378)].

flower (colour of the corolla) and leaves (polymorphism in the size and number of leaflets of the leaves). Additionally, some specimens show a phenology more typical in A. lagascana: loss of leaves mainly during the summer period, and early flowering period; other specimens have shown characteristics resembling $A$. terniflora: the flowering is later and the abscission often occurs with greater profusion during the Autumn-Winter period. Furthermore, the wildfire resilience of this hybrid should be remarked, a characteristic feature of $A$. lagascana but absent in A. terniflora and A. cytisoides.
Some variability among the studied specimens of A. $\times$ currasii was observed. This variation mainly affects floral and foliar characteristics such as the colour of the corollas and size polymorphism, dimensions and number of leaflets. Moreover, some specimens have the typical phenotypical behaviour of $A$. lagascana, with a loss of leaves mainly during the Summer period and an early flowering period; other specimens have flowers later and the abscission usually occurs more widespread during the Autumn-Winter period, which is more similar to $A$. cytisoides. 

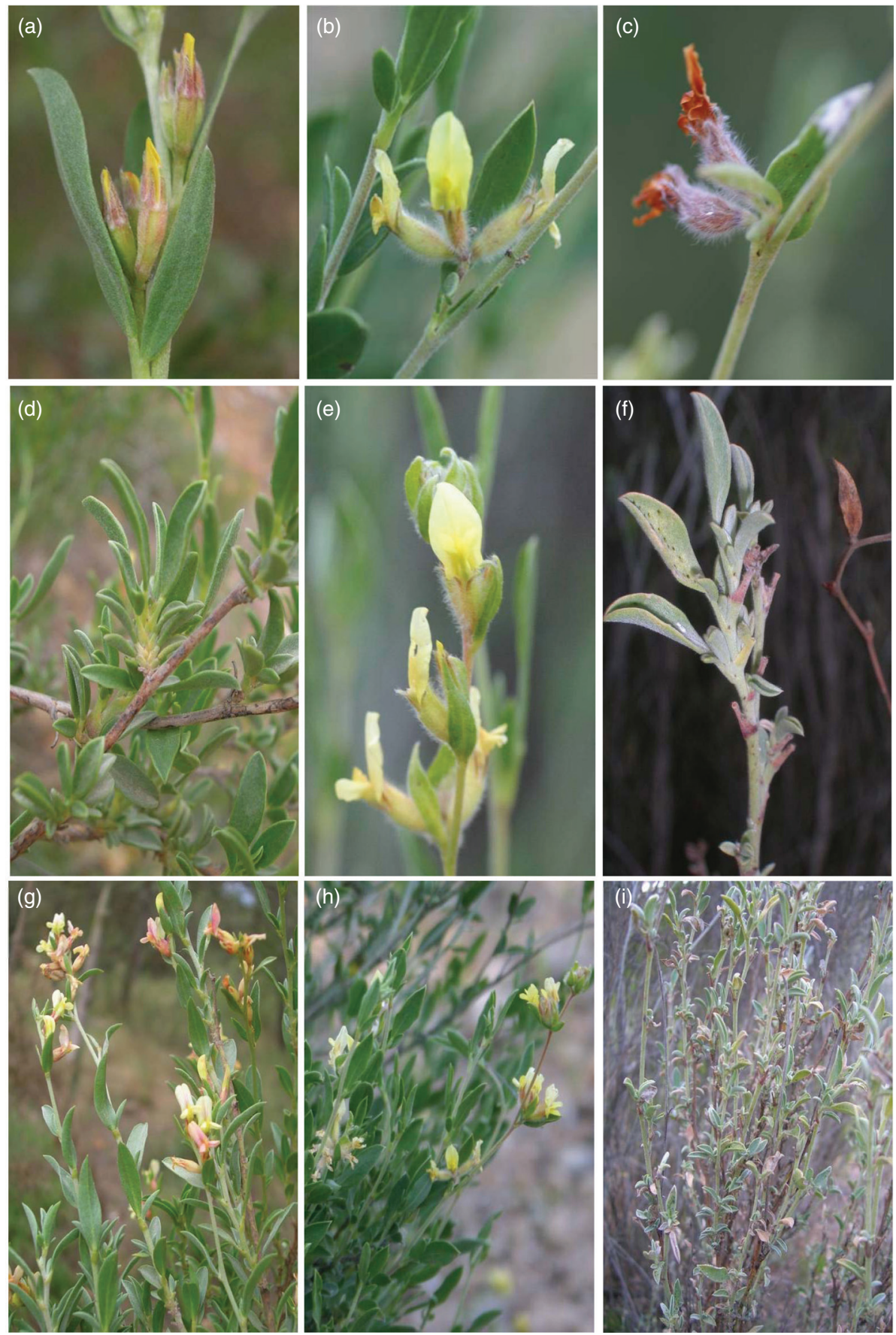

Fig. 3. Flowers, branches, and inflorescences of Anthyllis $\times$ fortuita (a, d, $\mathbf{g}$, left) and $A$. $\times$ currasii (b, $\mathbf{c}, \mathbf{e}, \mathbf{f}, \mathbf{h}, \mathbf{i}$, center and right).

\section{Habitat and ecology}

Anthyllis $\times$ currasii was found very close to the city of Valencia in "El Plantío-La Canyada" (Paterna), where one of the parents, A. sericea Lag. (Esteve, 1969), was observed coexisting with its two congeners $A$. cytisoides and $A$. terniflora for the first time in the Valencian Community (Moroder, 1927). For some of these taxa this location is at the edge of the northernmost limits of their respective areas of distribution (Fig. 4). They co-occur together with species such as Hippocrepis fruticescens Sennen, Erica multiflora L., Thymus piperella L., Ulex parviflorus Pourr., Rhamnus alaternus L., Pinus halepensis Mill., Rosmarinus officinalis L., and some interesting exclusive endemics of Valencia, such as Sideritis juryi Peris \& al. and Teucrium edetanum M.B. Crespo \& al. From a phytosociological perspective, the vegetation is part of the Levantine Iberian shrubbery series Rosmarinion officinalis Br.-Bl. ex Molinier (1934), inclusive into the Valencian endemic association Hippocrepido fruticescentis-Anthyllidetum lagascanae Stübing \& al. (1989, corr.), which develops on limestone soils rich in sand fraction. The bioclimatic profile of the territory is characteristically Mediterranean 


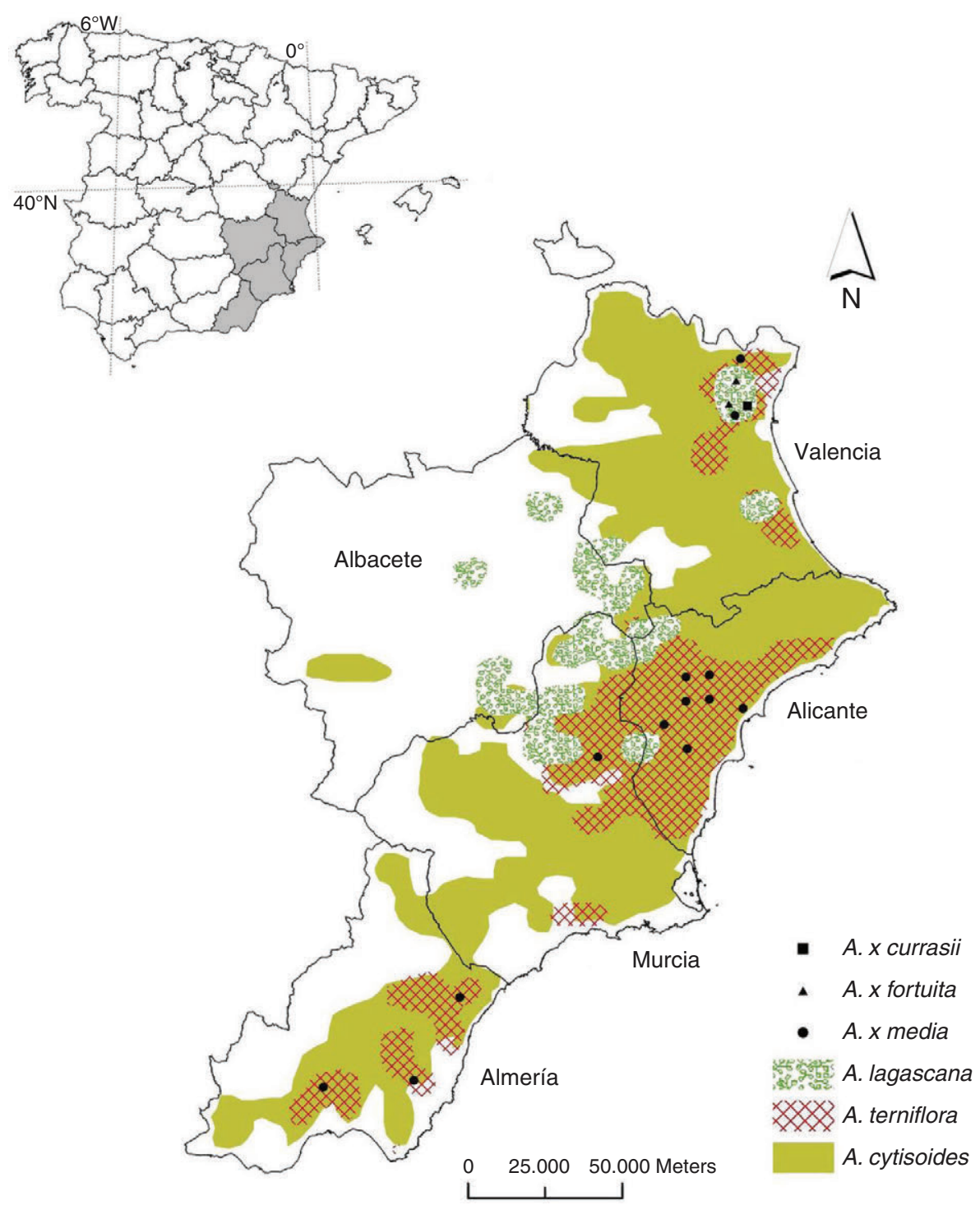

Fig. 4. Geographic distribution of Anthyllis hybrids and their parents in the Southeastern Iberian Peninsula.

pluviseasonal-oceanic with an upper Thermomediterranean thermotype and a dry lower ombrotype (Rivas-Martínez, 2007). Phytogeographically, the territory is assigned to the southern portion of Valencian-Tarraconense sector and northern portion of Setabensian sector, both from the Valencian-Catalonian-Provenzal-Balearic province (De la Torre \& al., 1996; Rivas-Martínez \& al., 2002; RivasMartínez, 2007).

\section{Conservation status}

Population censuses carried out to date have resulted in a total of 19 individuals for $A$. $\times$ fortuita, distributed over an area of approximately $2 \mathrm{~km}$. In contrast, $A . \times$ media and A. $\times$ currasii have only been found in an area that is not greater than $100 \mathrm{~m}^{2}$ with 39 and 10 specimens, respectively. Generally, the conservation of these species is covered passively through current general and autonomic legislation, thanks in part to the inclusion of $A$. lagascana as protected species throughout the Valencian Community (signed in Annex II of the
Order of the 20th Dec, 1985, Department of Agriculture and Fisheries), and more specifically thanks to the recent declaration of the Turia Natural Park (Valencia), which includes the largest populations of this species within the Valencian territory. Additionally, A. lagascana is recorded in Annex II of the declaration of Decree 70/2009 and Order 6/2013 on the establishment and regulation of the Valencian Catalog of Threatened Flora (Anonymous, 2009, 2013). Moreover, the Germoplasm Bank of the CIEF (Center for Forestry Research and Experimentation of Valencia Community) and the Botanical Garden of University of Valencia have preserved seeds of the parents, and the living plants are multiplied here from cuttings of the three hybrids hitherto described for the genus Anthyllis.

\section{Nomenclatural comments}

The nature of the nothotaxon presented here and previously described by Guara \& Ferrer (2006) represents intersubgeneric hybrids, which allows for the creation of a 


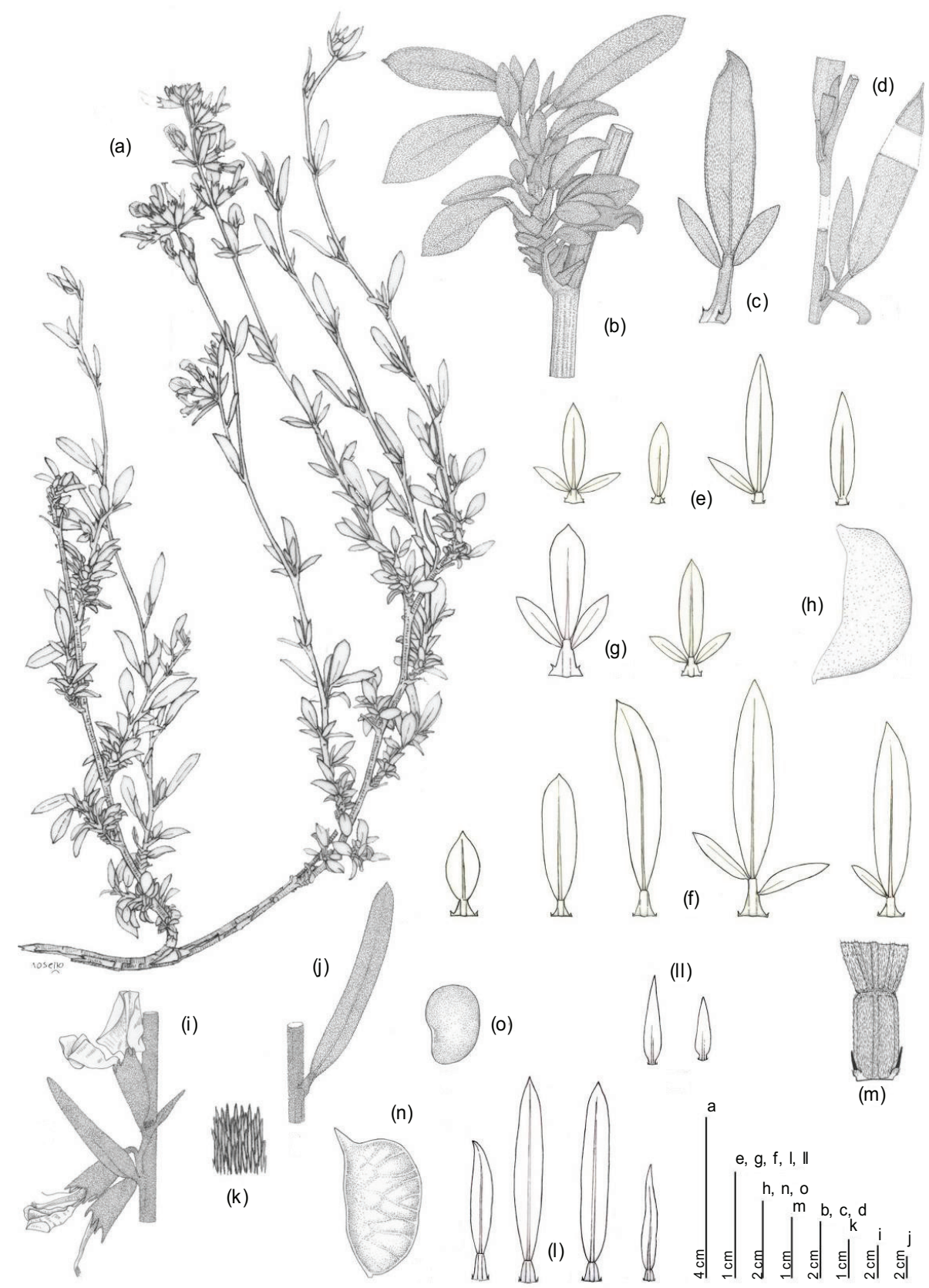

Fig. 5. Anthyllis $\times$ fortuita: $\mathbf{a}$, habit; $\mathbf{b}$, branch and leaves; $\mathbf{c}, \mathbf{d}$, leaves; e, bracts; $\mathbf{f}, \mathbf{g}$, leaves; $\mathbf{h}$, fruit. A. terniflora: $\mathbf{i}$, inflorescence detail; j, leaf detail; k, stem indumentum; I, leaves; II, bracts; $\mathbf{m}$, petiole and stipules; $\mathbf{n}$, fruit; $\mathbf{o}$, seed [a-h, M. Guara \& Mª José Ciurana s.n. (VAL 207804); i-o, P.P. Ferrer \& I. Ferrando s.n. (MA 776381)].

new nothosubgenus (see ICBN Art. H.7.1, McNeill \& al., 2012). Therefore, we propose the name Anthyllis nothosubgen. Ternijovis P.P. Ferrer, Roselló \& Guara, nothosubgen. nov. (A. subgen. Terniflora V.N. Tikhom \& D.D. Sokoloff $x$ A. subgen. Barba-Jovis V.N. Tikhom \& D.D. Sokoloff). It encompasses shrubby plants, unarmed, young branches crowded together at the base with persistent sheath petiole; distichous leaves, with 1-3 hairy leaflets and setaceous stipules (Fig. 8); inflorescences in almost sessile fascicles, with 1-7 axillary flowers, grouped in terminal lax spikes, entire or palmate bracts; campanulate calyx with triangular teeth, acuminate, almost equal; and, finally, somewhat stipitate fruit. This group includes the nothotaxon, which has been described here, and the hybrid A. × fortuita (Fig. 5).

\section{Identification key}

Based on Flora iberica (Benedí, 2000) here is presented a key that includes the three Iberian hybrids known until now in Antbyllis and their parents.

1. Flowers in axillary almost sessile fascicles, with peduncle $\leq 2 \mathrm{~mm}$, grouped in terminal lax spikes up to $20 \mathrm{~cm}$..... 2

1. Flowers in terminal pedunculate heads, with peduncle $>(5) 8 \mathrm{~mm}$ A. lagascana 


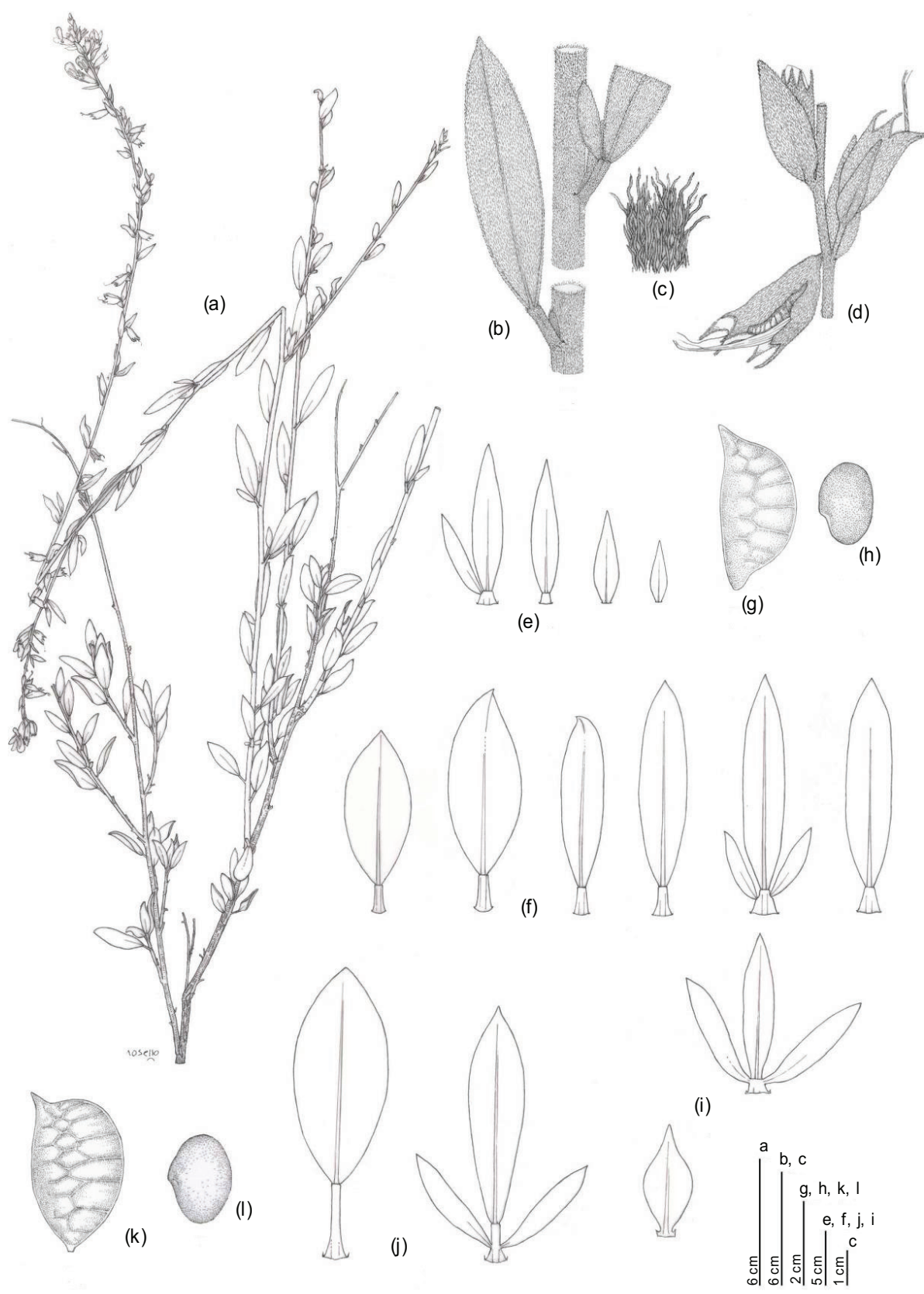

Fig. 6. Anthyllis $\times$ media: $\mathbf{a}$, habit; $\mathbf{b}$, stem and leaves; $\mathbf{c}$, stems indumentum; $\mathbf{d}$, inflorescence detail; e, bracts; $\mathbf{f}$, leaves; $\mathbf{g}$, fruit; $\mathbf{h}$, seed. $A$. cytisoides: i, bracts; j, leaves; k, fruit; I, seed. [a-h, P.P. Ferrer \& I. Ferrando s.n. (MA 776382); i-I, P.P. Ferrer \& I. Ferrando s.n. (MA 776379)].

2. Basal leaves distichous, with persistent petiole sheath; yellow flowers with a pink tonality

2. Basal leaves non distichous, without persistent petiole sheath; flowers always yellow.....

3. Calyxes pubescent with appressed hairs shorter than 0.3 $\mathrm{mm}$; inflorescences well developed

A. $\times$ fortuita

3. Calyxes very villous, with erect hairs nflorescences fewflowered

A. $\times$ currasii

4. Middle leaves usually trifoliate; flowers $\geq 9 \mathrm{~mm}$ long A. cytisoides

4. Middle leaves usually unifoliate, rarely trifoliolate, in this case with the central leaflet less than $8 \mathrm{~mm}$ wide, usually flowers are shorter than $9 \mathrm{~mm}$
5. Young branches with sericeous hairs; unifoliolate leaves with indumentum of appressed hairs; flowers 6-8 $\mathrm{mm}$; calyx with appressed indumentum .................................................... A. terniflora

5. Upper part of stems with pubescence \pm appressed and lower part curly; leaves sometimes bifoliate or trifoliate, with indumentum of curled hairs; flowers 7-9(12.5) mm; calyx villous A. $\times$ media

\section{ACKNOWLEDGMENTS}

Thanks to the curators of the different consulted herbaria for their help. Thanks to Amanda Brothers (Indiana University) for their help. 


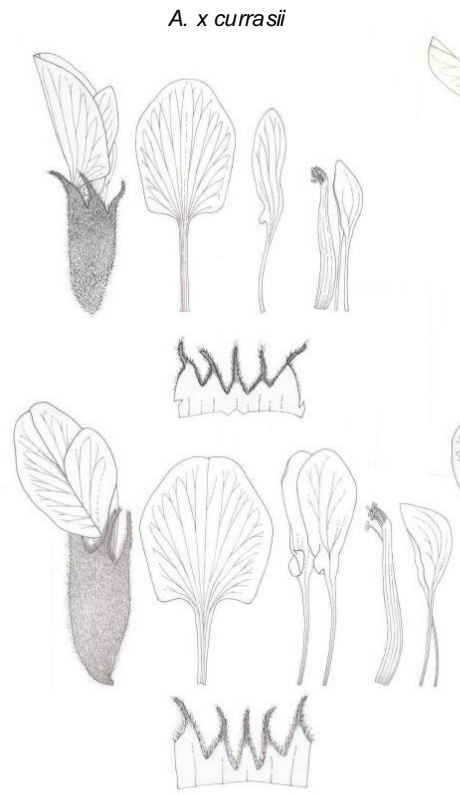

A. cytisoides
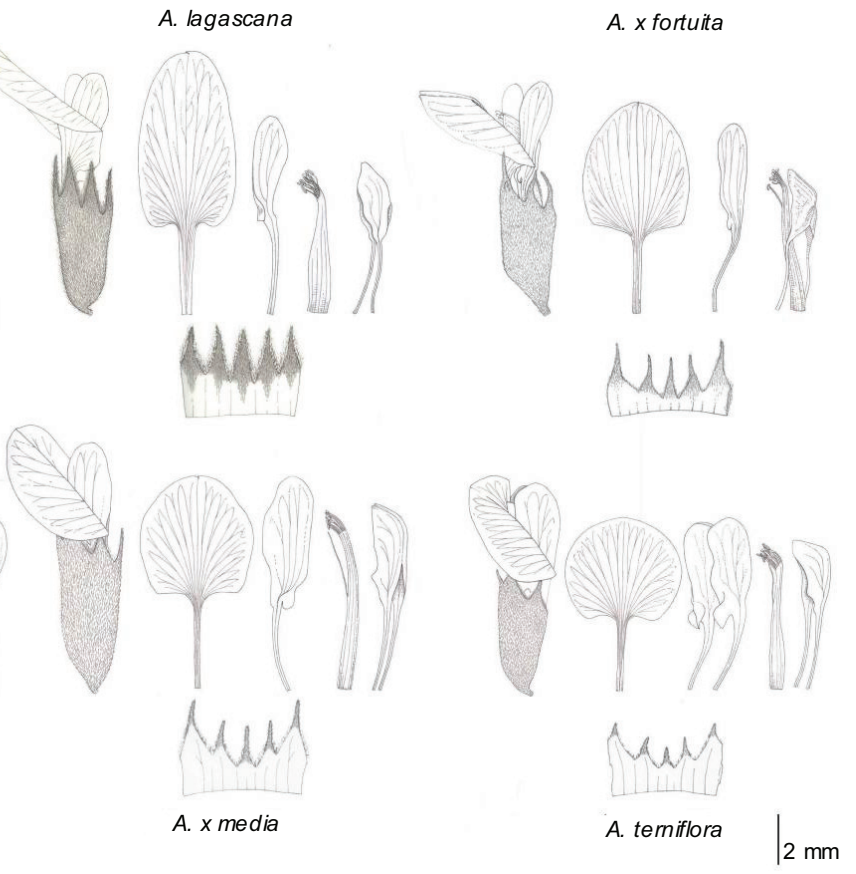

A. $x$ media

Fig. 7. Flowers and floral pieces of Anthyllis hybrids and their parents: banner, wing, stamens, keel, and calyx teeth (adaxial view).
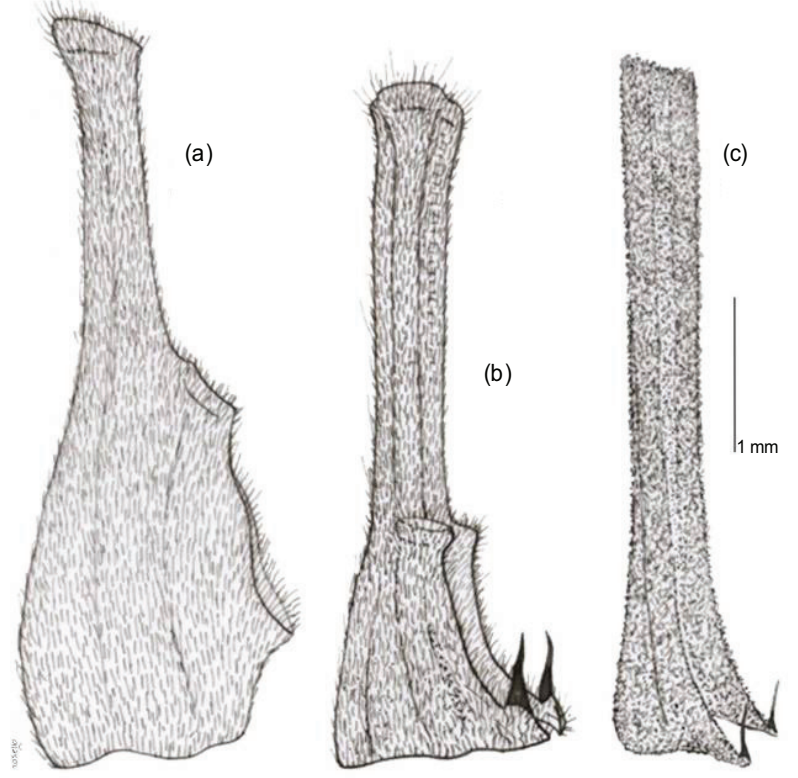

Fig. 8. Anthyllis lagascana: a, subpulvinate petiole. A. $\times$ currasii: $\mathbf{b}$, petiole almost subpulvinate and stipulate. A. cytisoides: c, stipulate petiole.

\section{REFERENCES}

Anonymous, 2009. Decreto 70/2009, de 22 de mayo, del Consell, por el que se crea y regula el Catálogo Valenciano de Especies de Flora Amenazadas y se regulan medidas adicionales de conservación. Diari Oficial de la Comunitat Valenciana (DOCV) 6021(25.05.2009): 20143-2016.

Anonymous, 2013. Orden 6/2013, de 25 de marzo, de la Conselleria de Infraestructuras, Territorio y Medio Ambiente, por la que se modifican los listados valencianos de especies protegidas de flora y fauna.

Diari Oficial de la Comunitat Valenciana (DOCV) 6996(04.04.2013): 8682-8690.

Benedí, C. 1995. Taxonomía del grupo de Anthyllis henoniana Coss. (Leguminosae): A. lagascana, nom. nov. Anales del Jardín Botánico de Madrid 53(2): 282-284.

Benedí, C. 1998. Consideraciones sobre el género Anthyllis L. (LoteaeLeguminosae) y su tratamiento en Flora iberica. Anales del Jardín Botánico de Madrid 56(2): 279-303.

Benedí, C. 2000. Anthyllis L. In: Talavera, S. \& al. (eds.), Flora iberica 7(2): 829-863. CSIC. Madrid.

Crespo, M.B. 1989. Contribución al estudio florístico, fitosociológico y fitogeográfico de la Serra Calderona (Valencia-Castellón). Tesis doctoral. Universitat de Valencia. Valencia.

Crespo, M.B. \& Manso, M.L. 1990. Notas sobre la vegetación de las dunas de Elche (Alicante). Ecologia 4: 67-88.

Cullen, J. 1968. Anthyllis L. In: Tutin, T.G. \& al. (eds.), Flora Europaea. Rosaceae to Umbelliferae 2: 177-182. Cambridge University Press. Cambridge.

De la Torre, A. 1988. Flora, vegetación y suelos de la Sierra del Maigmó (Alicante). Caja de Ahorros Provincial de Alicante. Alicante.

De la Torre, A., Alcaraz, F. \& Crespo, M.B. 1996. Aproximación a la biogeografía del sector Setabense (provincia Catalano-ValencianoProvenzal). Lazaroa 16: 141-158.

Degtjareva, G.A., Valiejo-Roman, C., Samigullin, T. \& Sokoloff, D.D. 2006. On generic rank and phylogenetic relationships of Dorycnopsis Boiss. (Leguminosae, Loteae). Anales del Jardín Botánico de Madrid 63(1): $41-50$.

Degtjareva, G.A.; Vallejo-Roman, C.M., Samigullin, T.H., Guara-Requena, M. \& Sokoloff, D.D. 2012. Phylogenetics of Anthyllis (Leguminosae: Papillionideae: Loteae): Partial incongruence between nuclear and plastid markers, a long branch problem and implications for morphological evolution. Molecular Phylogenetics and Evolution 62: 693-707. http://dx.doi.org/10.1016/j.ympev.2011.11.010

Esteve, F. 1969. Acerca del holotipo lagascano de Anthyllis sericea Lag. y localización de la especie en el SE y levante ibérico (nova spp. valentina). Ars Pharmaceutica 10: 67-73

Guara, M. \& Ferrer, P.P. 2006. Anthyllis $\times$ fortuita, un nuevo híbrido natural en el género Anthyllis L. (Leguminosae). Acta Botanica Malacitana 31: 171-172.

López González, G. 2004. On Anthyllis onobrychioides Cav. and the genus Dorycnopsis Boiss. (Leguminosae-Loteae). Anales del Jardín Botánico de Madrid 61(2): 181-184. http://dx.doi.org/10.3989/ajbm.2004.v61.i2.43 
Mateo, G. \& Crespo, M.B. 2014. Claves ilustradas para la Flora Valenciana. Colección Monografías de Flora Montibérica n. ${ }^{\circ}$ 6. Jaca.

McNeill, J., Barrie, F.R., Buck, W.R., Demoulin, V., Greuter, W., Hawksworth, D.L., Herendeen, P.S., Knapp, S., Marhold, K., Prado, J., Prud'homme van Reine, W.F., Smith, G.F., Wiersema, J.H. \& Turland, N.J. (eds.) 2012. International Code of Nomenclature for algae, fungi, and plants (Melbourne Code). Regnum Vegetabile 154.

Moroder, E. 1927. Una nueva planta para la región valenciana (Anthyllis sericea Lag.). Boletín de la Sociedad Española de Historia Natural 27(7):322-323.

Nanni, L., Ferradini, N., Taffetani, F. \& Papa, R. 2004. Molecular phylogeny of Anthyllis spp. Plant Biology 6: 454-464. http://dx.doi. org/10.1055/s-2004-820968

Rigual, A. 1984. Flora y Vegetación de la provincia de Alicante ed. 2. Instituto de Estudios Juan Gil-Albert. Alicante.

Rivas-Martínez, S. 2007. Mapa de series, geoseries y geopermaseries de vegetación de España [Memoria del Mapa de Vegetación Potencial de España. Parte 1]. Itinera Geobotanica 17: 1-436.

Rivas-Martínez, S., Díaz, T.E., Fernánez-González, F., Izco,J., Loidi, J., Lousã, M. \& Penas, A. 2002. Vascular plant communities of Spain and Portugal. Addenda to the syntaxonomical checklist of 2001. Itinera Geobotanica 15: 5-922.

Sagredo, R. 1987. Flora de Almería: Plantas vasculares de la provincia. Instituto de Estudios Almerienses. Almería.

Sánchez-Gómez, P. \& Guerra, J. 2003. Nueva flora de Murcia. Ed. Diego Marín. Murcia.

Serra, L. 2007. Estudio crítico de la Flora Vascular de la Provincia de Alicante: Aspectos Nomenclaturales, Biogeográficos y de Conservación. Ruizia 19

Sokoloff, D.D. 1997. Comparative study of fruit anatomy in the genus Anthyllis (Papilionaceae, Loteae) [in Russian]. Botanicheskii Zhurnal 82(10): 58-74.

Sokoloff, D.D. 2003a. On system and phylogeny of the tribe Loteae DC. (Leguminosae) [in Russian]. Bulletin of Moscow Society of Naturalists, Biological Series 108(3): 35-48.

Sokoloff, D.D. 2003b. Morphology and classification of the tribe Loteae $D C$. of the family Leguminosae [in Russian]. Dr. Sci. Thesis. Moscow.

Sokoloff, D.D. 2006. Cladistic analysis of the tribe Loteae (Leguminosae) based on morphological characters. In: Pandey, A. K. \& al. (eds.) Plant Taxonomy: Advances and Relevance: 45-81. CBS Publishers and Distributors. New Delhi.

Thiers, B. [2016]. Index Herbariorum: A global directory of public herbaria and associated staff. New York Botanical Garden's Virtual Herbarium. [http://sweetgum.nybg.org/ih/]

Tikhomirov, V.N. \& Sokoloff, D.D. 1996a. On the genera Hammatolobium Fenzl and Tripodion Medik. (Papilionaceae, Loteae s.1.). Feddes Repertorium 107(3-4): 209-217. http://dx.doi.org/10.1002/fedr.19961070307

Tikhomirov, V.N. \& Sokoloff, D.D. 1996b. On division of the genus Anthyllis L. (Papilionaceae, Loteae) into subgenera and sections [in Russian]. Byulleten' Moskovskogo Obshchestva Ispytatelej Prirody. Otdel biologicheskii 101(1): 61-73.

Vicedo, M. \& De la Torre, A. 1997. La Sierra de Crevillente: flora y vegetación. Instituto de Cultura Juan Gil-Albert. Alicante.

\section{APPENDIX 1}

A. $\times$ currasii P.P. Ferrer, Roselló \& Guara, nothosp. nov.

ESPAÑA. Valencia: Paterna (l'Horta), El Plantío-La Canyada, 30SYJ1579, $123 \mathrm{~m}, 23-\mathrm{V}-2008$, P.P. Ferrer \& I. Ferrando s.n. (MA 776378); ibidem (ABH 52762); ibidem (BC 990270); ibídem (VAL); Paterna, La Canyada, YJ1480, P.P. Ferrer s.n. (Herb. pers.); Paterna, La Canyada, YJ1579, P.P. Ferrer s.n. (Herb. pers.).

\section{A. cytisoides $L$.}

ESPAÑA. Albacete: Almansa, XJ7806, C. Obón s.n. (MUB 16094); Caudete, Sierra de la Oliva, XH7491, C. Obón s.n. (MUB 16259); Socovos, Barranco del Yesar, P. Sánchez s.n. (MUB 16693). Alicante: Guardamar, YH0613 (MUB 12177); Maigmó, YH0361, A de la Torre s.n. (MUB14620). Almería: Huércal-Overa, F. Beltrán s.n. (VAL 170515); Sierra Almagro, WG9635, A. Lahova s.n. (MUB 44455); carretera a Gergal, WG40, F. Alcaraz s.n. (MUB 2180); Pulpí, Terreros, XG1735, M. Miras s.n. (MUB); Vélez Rubio, WG8366, A. García Gea s.n. (MUB 19600; MUB 19443). Castellón: Oropesa, camp de batalla,
J. Tirado \& C. Villaescusa s.n. (VAL 20192); Peñíscola, C. Villascusa \& J. Tirado 13 (VAL 20196); Segorbe, C. Pau s.n. (VAL 180113); Vilafamés, vessant nord del Mollet, J. Tirado \& C. Villaescusa s.n. (VAL 20189). Granada: Alamedilla, C. Morales, L. Baena \& F. B. Navarro s.n. (BC 862940); Fonelas. Los Llanillos, Rafael Sánchez Pérez s.n (BC 862927) Entre Lanjaron y Orgiva, Oswaldo Socorro \& M. C. Espinar s.n. (BC 862926). Málaga: Gaucín, C. Vicioso s.n. (VAL 170504). Mallorca: Palma à Cas Catala, F. Sennen s.n. (VAL 170506); Murcia: Abanilla, Puerto de Barinas, XH6836, F. Alcaraz s.n. (MUB 8812); Barqueros, I. Bosque s.n. (MUB 47169); Bullas, La Rana, XH1808, F. Alcaraz s.n. (MUB 5966); Cehegín, Sierra de la Puerta, XH0825, C. Selma s.n. (MUB 20276): Calasparra, Sierra del Molino, XH1934, Fdez.-Delgado s.n. (MUB 3777); Caravaca, Casa de Guindarra, XH0218, Egea s.n. (MUB 9181); Caravaca, Buena Vista, WH9818, C. Selma s.n. (MUB 20275); Cartagena, La Algameca, XG7561, E. J, Sanz S.n. (MUB 2972); Cieza, Rambla del Moro, XH4232, F. Alcaraz s.n. (MUB 5718); Cierza, Puerto de La Mala Mujer, XH3045, F. Alcaraz s.n. (MUB 3698); Espinardo, XH6010, F. Alcaraz s.n. (MUB 3418); Espinardo, D. Ferrer s.n. (MUB 13138); Sierra de Carrascoy, A. Múller s.n. (MUB 46436); Fortuna, Sierra Baño, XH6432, F. Alcaraz s.n. (MUB 8813); Fortuna, Cabezos Negros, S. Gomariz \& I. Pamies s.n. (MUB 46928); Lorca, Pantano de Puentes, XG07, Periago \& Miñarro s.n. (MUB 4432); Mazarrón, XG56, I. Fuentes s.n. (MUB 12252); Molina, El Fenazar, Pineda, Salinas \& Ruíz s.n. (MUB 36277); Moratalla, Río Benamar, WH9626, C. Selma s.n. (MUB 20277); Moratalla, Collado de los Vinateros, WH9637, C. Selma s.n. (MUB 20274); Moratalla, Sierra de Pajares, XH1345, F. Alcaraz \& T. Lozano s.n. (MUB 4716); Puerto Lumbreras, Monte de Vilerda, XG05, J. Guira s.n. (MUB 198); Jumilla, Cerro de la Rosa, XH5654, F. Alcaraz s.n. (MUB 4844); Jumilla, Sierra Larga, XH4549, F. Alcaraz s.n. (MUB 5398); Jumilla, Los Molinos, A. I. Jiménez s.n. (MUB 39582); Jumilla, Sierra Cingla, XH4971, F. Alcaraz s.n. (MUB 8811); Jumilla; A. I. Jiménez s.n. (MUB 39583); Santomera, embalse de Santomera, XH6718, F. Alcaraz s.n. (MUB 2675); Sierra de Espuña, XG3590, A. Robledo s.n. (MUB 15101): Sierra de Columbares, XG79, M. J. Quiles s.n. (MUB 4618); Sierra Ricote, XH4324, M. Hurtado \& P. del Olmo s.n. (MUB 25214); Sierra del Puerto, XG6197, F. Alcaraz s.n. (MUB 4822); Teatinos, Sierra de la Cresta, XH6500, F. Alcaraz s.n. (MUB 2973); Torreagüera, A. Müller s.n. (MUB 46513); Totana, XG2881, A. Robledo s.n. (MUB 17250); Yecla, Sierra de Salinas, Ana, Flora y Ma José s.n. (MUB 39833); Yecla, Los Algezares, XH6173, F. Alcaraz s.n. (MUB 8808). Tarragona: Torredembarra, J. M. Ninot s.n. (MUB 21060). Valencia: Ador, YJ40, J. Güemes s.n. (VAL 4316); Alcoy, Sierra de Mariola, en la boca del barranco del Cinc, YH1887, M. Pons Mora s.n. (VAL 188822); Alcira, E. Moroder s.n. (VAL 170509; VAL 170507); Barraix, Sierra Calderona, YJ29, J. Güemes s.n. (VAL 3691); Benagéber, hacia el embalse, XJ69, García Navarro s.n. (VAL 91566); Beniatjar, Serra de Marxalets, YJ20, Nebot s.n. (VAL 52904); Bicorp, Barranco Pau, XJ9132, J.J. HerreroBorgoñón s.n. (ABH 30360); Calles, Colado del Aire, XK7703, J.J. Herrero-Borgoñón s.n. (ABH 30205); ibídem, hacia Higueruelas, XK70, Murgui Romero s.n. (VAL 55892); Carcagente, Mont Blanc, YJ22, Piera Gabardó s.n. (VAL 54047); Chera, XJ78, Olmedo s.n. (VAL 5811); Chulilla, XJ89, V. Deltoro s.n. (VAL 85827); Cofrentes, Las Salinas, XJ6747, J.J. Herrero-Borgoñón s.n. (ABH 30253); El Saler, Devesa del Saler, YJ35, Burgaz, Mateu, Salvador \& Güemes s.n. (VAL 8351); ibídem, Mateo s.n. (VAL 72205); ibídem, E. Moroder s.n. (VAL 170505); Estivella, El Garbí, YJ2597, J. Riera 3889 (VAL 40656); ibídem, M. Costa \& al., s.n. (VAL 120748); Jalance, Puntal del Puente, XJ6541, J.J. Herrero-Borgoñón s.n. (ABH 30271); La Barraca, E. Moroder s.n. (VAL 170513); Lliria, YJ0591, M. B. Crespo s.n. (ABH 2825); ibídem, Bodegas del Campo, XK9700, J.J. Herrero-Borgoñón s.n. (ABH 30583); Loriguilla, pr. embalse de Loriguilla, XJ79, Vila s.n. (VAL 99707); Museros, F. Beltrán s.n.(VAL 170514); Paterna, El Plantío-La Canyada, YJ11579, P.P. Ferrer \& I. Ferrando S.n. (MA 77679); Pedralba, XJ98, Mateu \& al., s.n. (VAL 43894; VAL 43755); Picassent, V. Martí s.n. (VAL 170517); Marines, castillo, YJ10, Mateu \& al. s.n. (VAL 44050); Pinet, Mansanet \& Aguilella s.n. (VAL 6028); Porta-Coeli, E. Moroder S.n. (170511); Portichol, F. Beltrán s.n. (VAL 170516); Puebla de Vallbona, Lloma Llarga, YJ18, M. B. Crespo s.n. (VAL 72762); Puzol, E. Moroder s.n. (VAL 170512; VAL 170510; VAL 170508); ibídem, Monte Picayo, YJ39, Crespo, Nebot, Olcina \& Andreu s.n. (VAL 53830); Requena, Casas del Río, XJ65, García Navarro s.n. (VAL 91543); Sagunto, Monte Picayo, Manso, Roselló \& J. L. Solanas s.n. (ABH 2504); ibídem, YJ39, Mateo s.n. (VAL 48964); ibídem, P. Capell s.n. (VAL 180507); Serra, Balsa de San Antonio, YJ2197, J.J. Herrero-Borgoñón s.n. (ABH 30253); ibídem, Barranco de la Bigüela, YJ19, Costa Pons s.n. (VAL 66160); ibídem, 
frente a el Tancat de Porta-Coeli, YJ1695, A. Aguilella, O. Barberá \& A. Marco s.n. (VAL 12536); ibídem, I. Docavo s.n. (VAL 3355); ibídem, Font del Berro, A. Aranda \& al., s.n. (VAL 188537; VAL 188169); ibídem, Castillo de Serra, YJ29, M. B. Crespo s.n. (VAL 53859); Simat de Valldigna, collado de la Visteta, YJ32, Torres s.n. (VAL 99995); Sinarcas, pr. Charco Negro, XK50, García Navarro s.n. (VAL 91699); Olocau, M J J. Morán \& R. Figuerola s.n. (VAL 120749); Torres-Torres, YK20, G. Mateo s.n. (VAL 53201); Xilxes, La Condesa, C. Varea s.n. (VAL 187052). Vallada, M. Llopis s.n. (VAL 170518)

MARRUECOS. Gueznaia: Montes de Bu-IIma, F. Sennen \& Mauricio s.n. (BC 80756). Uixan: Beni Bu Ifrur, F. Sennen \& Mauricio s.n. (BC 80757).

\section{A. $\times$ fortuita Guara \& P.P. Ferrer}

ESPAÑA. Valencia: Paterna, El Plantío-La Canyada, YJ1480, M. Guara \& $M^{a}$ José Ciurana s.n. (VAL 157280, holotypus); ibídem (VAL 207804 isotypus); ibídem (MA 776383, isotypus); ibídem (ABH 48093, isotypus); ibídem (BC 990269, isotypus); ibidem, YJ1480, P. Pablo Ferrer s.n. (VAL 207805); ibídem, P.P. Ferrer s.n. (SALA 142399); ibídem, YJ1579, P.P. Ferrer s.n. (VAL 202268); Paterna, La Canyada, YJ1580, P.P. Ferrer s.n. (Herb. pers.); Paterna, La Canyada, YJ1579, P.P. Ferrer s.n. (Herb. pers.).

\section{A. lagascana Benedí}

ARGELIA. Djelfa: Wilaya de Djelfa, sur le plane sud du Djebel Senalba, à environs $35 \mathrm{~km}$ au SW de Djelfa, A. Dubois s.n. (VAL 34987)

ESPAÑA. Albacete: Agramón, F. Esteve s.n. (MA 188046); Almansa, Sierra del Mugrón, XJ6014, C. Obón s.n. (MUB 16240); ibídem, XJ5608, C. Obón s.n. (MUB 16237); ibídem, G. Mateo \& Mansanet s.n. (VAL 770338); ibídem, G. Mateo \& R. Figuerola s.n. (VAL, ex VAB 842067); Afueras de Almansa, XH6496, C. Obón s.n. (MUB 16262): Caudete, J. Fernández Piqueras 370 (MA 198288); Caudete, G. Mateo \& R. Figuerola s.n. (VAL 842068); ibídem, XH7182, F. Alcaraz s.n. (MUB) Hellín, Minateda, XH2357, F. Alcaraz s.n. (MUB 5744); ibidem, junto a la estación de Agramón, XH2051, V. J. Arán \& al., 6061 (VAL 179655); ibídem, Agramón, XH2051, F. Alcaraz s.n. (MUB 3652); ibídem XH1463, G. López 2995 (VAL 16398); de Chinchilla a Albacete, Lagasca s.n. (MA 151155); entre Cieza y Hellín, J. Borja s.n. (MA 178730); La Gila, J. Peris \& R. Figuerola s.n. (VAL2339); ibídem, Sierra de la Caballa, J. Peris s.n. (VAL 10017). Alicante: Canyada, Serra de la Solana, pr. transformador, XH8885, L. Serra \& A. Bort S.n. (ABH 44775); ibídem, La Canyada de Bihar, XH8885, E. Estrelles, J. Prieto \& L. Serra s.n. (VAL 142573); Villena, Sierra de la Lácera, XH7380, L. Serra s.n. (ABH 19970); ibídem, E. Estrelles, J. Prieto \& L. Serra s.n. (VAL 142569); ibídem, Rambla de la Toconera, XH7480, E. Estrelles, J. Prieto \& L. Serra s.n. (VAL 142571); ibídem, Estrecho Pipa, XH7575, L. Serra s.n. (ABH 19932); ibídem, a final del Estrecho Pipa, XH7675, E. Estrelles, J. Prieto \& L. Serra s.n. (VAL 142570); ibídem, XH7775, J. Riera 4600 (VAL 189548); ibídem, Cerro de los Mojones, XH7276, E. Estrelles, J. Prieto \& L. Serra s.n. (VAL 142570); ibídem, Casas del Rey, XH7376, E. Estrelles, J. Prieto \& L. Serra s.n. (VAL 142572). Murcia: Cieza, Puerto de la Mala Mujer, Alcaraz \& Sánchez s.n. (MUB 27185); ibídem, XH3045, F. Alcaraz s.n. (MUB3686); Cieza, XH4232, F. Alcaraz s.n. (MUB 6298); Yecla, Altos de Caudete, Ana, Flora y Ma José s.n. (MUB 39896); carretera de Madrid Km 331, Caridad Selma s.n. (MUB 42785); Jumilla, A. Isabel Jimenez s.n. (MUB 39584); Jumilla, Sierra Larga, XH4650, F. Alcaraz s.n. (MUB 5347); Jumilla, Sierra de la Cingla, XH4971, F. Alcaraz s.n. (MUB 8815); Yecla, Puerto de Jumilla, XH5973, F. Alcaraz s.n. (MUB 7147); ibídem, B. Casaseca, E. F. Galeano \& J. Mansanet s.n. (MA 188384); Yecla, Montes del Portillo, XH7080, F. Alcaraz s.n. (MUB 8814); Yecla, Cerro Colorado, XH6779, F. Alcaraz s.n. (MUB 8816). Yecla, Cerro La sin Puerta, XH5987, F. Alcaraz s.n. (MUB 8817). Valencia: Paterna, La Cañada, S. Rivas Goday s.n. (VAL 120784); ibídem, F. Beltrán s.n. (VAL 170496); ibídem, Borja \& Mansanet s.n. (VAL 120783); ibídem, J. B. Peris, F. Esteso \& J. Pinillos s.n. (VAL 120758); ibídem, A. Aguilella \& G. Mateo s.n. (VAL 6022); ibídem, M. Costa s.n. (VAL 120762); ibídem, YJ17, C. Sánchez s.n. (VAL 881529); ibídem, J. Lagunas s.n. (VAL 81904); ibídem, M. L. Manso, M. B. Crespo \& J. Güemes s.n. (VAL 14323); ibídem, YJ17, E. M. Baeza Baus s.n. (ABH 4358); ibídem, YJ1579, P.P. Ferrer \& I. Ferrando s.n. (MA 776380); ibídem, hacia La Eliana, YJ1481, Pardo González s.n. (VAL 74018); ibídem, colinas de San Antonio, Cuchillo s.n. (VAL 86392); ibídem, Sanchiz s.n. (VAL 58412); ibídem, G. Mateo \& A. Aguilella s.n. (VAL 48239); ibídem, G. Mateo \&
A. Aguilella s.n. (VAL 48240); ibídem, J. Riera 2704 (VAL 38654); ibídem, G. Mateo s.n. (VAL 108289); ibídem, A. Giner s.n. (VAL 108192); ibídem, J. Riera \& F. Marco s.n. (VAL 40874), ibídem, S. Rivas Goday s.n. (MA 165835), ibídem, Dehesa del Mardor, J. Borja s.n. (MA 169151; MA 169152; MA 171581; 187144). Paterna, La Vallesa, XJ1476, J. Fabado \& C. Torres s.n. (VAL 182992); Pedralba, barranco del Portet, microrreserva de flora, XJ9284, J. Prieto, C. Torres \& J. Fabado s.n. (VAL 175724; VAL 183465)

\section{A. $\times$ media Pau}

ESPAÑA. Alicante: Alicante, Cabo Huerta, YH2748, M. B. Crespo s.n. (ABH 3832); Barranco de San Miguel de Salinas, A. Rigual s.n. (VAL 138746; VAL 138748); Benidorm, Serra Gelada, YH96, L. Pereira s.n. (ABH 50743); Crevillente, Emblase de Crevillente, XH9337, M. Vicedo, A de la Torre et col. s.n. (ABH 8526); Elche, La Marina, M. B. Crespo s.n. (ABH 2845; VAL, ex VAB 892750); Elda, Bateig, XH9258, 420 m, A. Juan, I. Juan \& P. Vila s.n. (ABH 52484); Monóvar, Sierra del Reclot, Bco. de Cavarrasa, XH8149, A. Navarro, M. B. Crespo, Juan, Serra \& Camuñas s.n. (ABH 31964); Sierra de las Águilas, YH0650, M. B. Crespo, Serra, A. Juan \& Camuñas s.n. (ABH 18498); Petrel, Arenal de Petrel, XH9465, A. Juan s.n. (ABH 18476); Maigmó, YH0361, A. de la Torre s.n. (MUB 14634); Maigmó YH0361, A. de la Torre s.n. (MUB 14655). Almería: Santa Fe, C. Pau 204 (MA 65198; BC 65198, lectotypus); Along old road to Sorbas from Carboneras junction of autovia, cerro del Almendral, $37^{\circ} 02^{\prime} \mathrm{N}-2^{\circ} 03^{\prime}$ W, S. L. Jury 17257 (MA 611099); Nijar, F. Alcaraz s.n. (MUB 9935); Sierra Almagro, XG0036, A. Lahova s.n. (MUB 44456); Tabernas, Desierto de Tabernas, sine coll., s.n. (GDA 53350); Entre Vera, Sorbas y Tabernas, M. Losa \& S. Rivas Goday s.n. (VAL 120766; VAL 2811). Murcia: Fortuna, Sierra de la Pila, XH5934, F. Alcaraz s.n. (MUB 1304); Sierra de Carrascoy, camino de las Yeseras, J. Varo S.n. (MGC 4824). Valencia: entre Bétera y Náquera, C. Benedí \& J. Vicens 1057 (GDA 50902); La Cañada, A. Aguilella s.n. (VAL 185250); Lliria, alrededores del cementerio, J. Peris \& G. Stübing s.n. (VAL 11959; VAL 11276); Náquera, Mont Ros, M. B. Crespo \& Manso s.n. (VAL 57101); Paterna, El Plantío-La Canyada, YJ11579, P.P. Ferrer \& I. Ferrando s.n. (MA 776382). Serra, Porta-Coeli, YJ19, M. B. Crespo \& Manso s.n. (VAL 57094); ibídem, sanatorio de Porta-Coeli, YJ19, G. Mateo \& M. B. Crespo s.n. (VAL 65444); Olocau, Catxirulo de Turó, YJ19, M. B. Crespo \& Manso s.n. (VAL 57093).

\section{A. terniflora (Lag.) Pau}

ESPAÑA. Alicante: Maigmó, YH0460, A. de la Torre s.n. (MUB 20332); Elche, pantano del Vinalopó, F. Alcaraz S.n. (MUB 10058); Monte Hurchillo, XH81, M. Garre s.n. (MUB 14323); Benidorm, F. Alcaraz \& cols. s.n. (MUB 48107); Cañada larga, XH91, M. Garre s.n. (MUB 12895); ibídem, F. Alcaraz s.n. (MUB 22836). Almería: Antax, Cerro María, WG92, J. Guirao s.n. (MUB 5893); Cuevas de Vera, Rivas Goday s.n. (MUB 30584); entre Abla y Doña María, J. Fernández Casas s.n. (MA 196554); de Mojácar a Turre, S. Rivas Goday s.n. (MA 259784 259786); Los Molinos del Río de Aguas, A. Charpin \& C. Defferrard 16679 (MA 259782): Pechina, alrededores del campamento militar S. Silvestre s.n. (MA 191509); Sierra Almagro, XG0036, A. Lahova s.n. (MUB 44457); Tabernas, Díaz, Muñoz \& Ruiz de Clavijo s.n. (MA 259785); Vers Uleila de Campo, Los yesos, a $3 \mathrm{~km}$ au N de la localité, D. Podlech \& W. Lippert 6651 (MA 279445); Vizcaíno, Pulpi, XG0638, A. Lahova \& F. Alcaraz s.n. (MUM); Yesos de Zugena, WG8430, A. Lahova s.n. (MUB 44458). Murcia: Abanilla, Sierra Abanilla, XH7431, F. Alcaraz s.n. (MUB 6282); Abanilla, pr. oppidulum Abanilla, Leal, Muñoz Garmendia, Ortiz \& Pueche 1713 (MA 208118); Águilas, Sierra En Medio (MUB 33222), Águilas, A. Robledo s.n. (MUB 22835); Fortuna, Sierra de La Pila, Puerto Frío, XH6038, F. Alcaraz s.n. (MUB 1211); Fortuna, Sierra de la Pila, XH5934, F. Alcaraz s.n. (MUB 1084); Fortuna, La Garapacha, XH5935, F. Alcaraz S.n. (MUB 359); Cieza, Puerto de La Mala Mujer, XH3046, F. Alcaraz S.n. (MUB8810); Cañada Umbría, XH80, M. Garre s.n. (MUB 14151); Fuente Álamo, Sierra de los Gómez, XG56, sine coll., s.n. (MUB 14193). Molina, El Fenazar, Pineda, Salinas \& Ruíz s.n. (MUB 36276); Mazarrón, Sierra de las Moreras, prope ermita de Ramonete, Blanché \& J. Molero s.n. (MA 259783); Molina, Albarda XH5624, F. Alcaraz s.n. (MUB 8804); Jumilla, Sierra Larga, XH4449, F. Alcaraz s.n. (MUB 8807); Jumilla, Viña Pi, XH6050, F. Alcaraz s.n. (MUB 8806); Santomera, pantano de Santomera, XH61, F. Alcaraz s.n. (MUB4778); Ulea, proximidades Rambla Salvador, XH4726, F. Alcaraz 
s.n. (MUB 2251). Valencia: Bétera, carretera hacia Náquera km 15, YJ19, M. B. Crespo \& J. Güemes s.n. (VAL 23895); Godella, A. Aguilella s.n. (VAL 9954); ibídem, hacia Paterna, Mateo s.n. (VAL 105517); La Eliana, urbanización Hendaya, YJ18, Ninet Peña s.n. (VAL 64264); La Pobla de Vallbona, Lloma Llarga, YJ1289, M. B. Crespo s.n. (ABH 6196); ibídem, M. B. Crespo s.n. (ABH 1845); ibídem, M. B. Crespo s.n. (ABH 5227); Liria, alrededores del cementerio, J. Peris \& G. Stübing s.n. (VAL 1208329; Náquera, Pla de l'Estepar, YJ2090, J. J. Herrero-Borgoñón s.n. (ABH 30580); ibídem, loma Masapedro, YJ28, M. B. Crespo s.n. (VAL 76124); ibídem, J. B. Peris \& G. Stübing s.n. (VAL 120790); Paterna, La Cañada, YJ17, R. Figuerola \& Ma José Morán s.n. (MUB 27831); El Plantío-La Canyada, YJ11579, P.P. Ferrer \& I. Ferrando s.n. (MA 776381); ibidem, R. López s.n. (VAL 58424); ibídem, Mateu s.n. (VAL 43991); ibídem, R. Figuerola \& Ma José Morán s.n. (ABH 32872); ibidem, S. Rivas Goday s.n. (MA 165834); ibidem, YJ17, Mateu s.n. (VAL 43992); ibídem YJ1579, J. Riera 2711 (VAL 38661); Puebla de Vallbona, YJ18, M. B. Creso s.n. (VAL 47931); ibídem, Mateu s.n.
(VAL 43993); ibídem, hacia Ribarroja del turia, YJ08, A. Aguilella s.n. (VAL 54267; VAL 54266); Serra, Porta Coeli, YJ1691, F. Puche \& M. B. Crespo s.n. (ABH 9412); ibídem, Mateo s.n. (VAL 51940); ibídem, hacia el sanatorio de Porta-Coeli, Mateo \& M. B. Crespo s.n. (VAL 5445); ibídem, frint al tancat de Porta-Coeli, YJ1695, A. Aguilella, O. Barbera \& A. Marco 30 (VAL 12537); ibídem, P. García-Fayos s.n. (VAL 3898); ibídem, cerca Cruz de Gracia, YJ1979, M. B. Crespo s.n. (ABH 2645); ibídem, YJ19, I. Docavo s.n. (VAL 44375); Torrente, La Foia del Vedat, J. Peris s.n. (VAL 120788); Olocau, YJ19, Mateu \& al., s.n. (VAL 44295; VAL 44294); ibídem, Carda Usó s.n. (VAL 67792).

Editor asociado: Inés Álvarez Recibido: 5-VII-2012 Aceptado: 5-VII-2013 